\title{
Thermal and Photochemical Switching of Conformation of Poly(ethylene glycol)-Substituted Cyclodextrin with an Azobenzene Group at the Chain End
}

Youhei Inoue, Paul Kuad, Yasushi Okumura, Yoshinori Takashima, Hiroyasu Yamaguchi, and Akira Harada*

Department of Macromolecular Science, Graduate School of Science, Osaka University, 1-1 Machikaneyama, Toyonaka, Osaka, 560-0043, Japan

E-mail: harada@chem.sci.osaka-u.ac.jp

\section{Contents}

Materials, Measurements, and Synthesis.

\section{Additional Experiments}

Figure S1. ${ }^{1} \mathrm{H}$ NMR spectra of 6-trans-Az-PEG600-HyCiO- $\beta$-CD in $\mathrm{D}_{2} \mathrm{O}$ at different concentrations.

Figure S2. Dependence of the diffusion coefficient of 6-Az-PEG600-HyCiO- $\beta$-CD in $\mathrm{D}_{2} \mathrm{O}$ on the concentration.

Figure S3. Partial 2D ROESY ${ }^{1} \mathrm{H}$ NMR spectrum of 6-cis-Az-PEG600-HyCiO- $\beta$-CD in $\mathrm{D}_{2} \mathrm{O}$ at $1 \mathrm{mM}$ at $1{ }^{\circ} \mathrm{C}$.

Figure S4. ${ }^{1} \mathrm{H}$ NMR spectra of 6-cis-Az-PEG600-HyCiO- $\beta$-CD in $\mathrm{D}_{2} \mathrm{O}$ at different concentrations.

Figure S5. Circular dichroism and UV-vis spectra of 6-trans-Az-PEG600-HyCiO- $\beta$-CD and 6-cis-Az-PEG600-HyCiO- $\beta$-CD in aqueous solutions. 


\section{Materials.}

p-Aminoazobenzene was obtained from Wako Pure Chemical Industries. Other materials are the same as reported previously. ${ }^{6}$

\section{Measurements.}

${ }^{1} \mathrm{H}$ NMR spectra were recorded at $400 \mathrm{MHz}$ on a JEOL-GSX 400 spectrometer. $2 \mathrm{D}{ }^{1} \mathrm{H}$ ROESY NMR spectra were recorded at $600 \mathrm{MHz}$ on a VARIAN UNITY plus NMR spectrometer. Chemical shifts were referenced to the solvent values $(\delta=4.70 \mathrm{ppm}$ for HOD, $\delta=2.50 \mathrm{ppm}$ for DMSO- $\left.d_{6}\right)$ and the external standard in the solvent $(\delta=1.96 \mathrm{ppm}$ for acetonitrile in $\mathrm{D}_{2} \mathrm{O}$ ). The bipolar pulse pair stimulated echo (BPPSTE) pulse sequence was applied for the pulsed field gradient (PFG) NMR measurements. The time separation of pulsed field gradients and their duration were 0.10 and $1.1 \times 10^{-3} \mathrm{~s}$. Positive-ion matrix assisted laser desorption/ionization time-of-flight (MALDI-TOF) mass measurements were performed on a Shimadzu/ KRATOS AXIMA-CFR spectrometer with 2,5-dihydroxy benzoic acid as matrix, $\alpha-\mathrm{CD}$ and insulin as standard, and $\mathrm{NaCl}$ as cationizing agent. Preparative reversed-phase chromatography was performed with Waters Delta 600 system (column: SunFireTM Prep $\mathrm{C}_{18} 19 \times 150 \mathrm{~mm}$ ). Light irradiation experiment was performed using an Ushio Inc. $500 \mathrm{~W}$ Xe lamp equipped with a Hoya UV34 cutoff filter and a Hoya U340 band-pass filter for UV light irradiation or with a Hoya Y45 for visible light. The distance between the sample cell and the lamp was fixed at $0.4 \mathrm{~m}$. Circular dichroism and UV-vis spectra were recorded on a JASCO J820 spectrometer in water with $0.1 \mathrm{~cm}$ cell at room temperature.

\section{Synthesis.}

Mono-6-O-[4-poly(ethylene glycol) 600 acid-hydrocinnamoyl]- $\beta$-CD (6-PEG600acid-HyCiO- $\beta$-CD).

This compound was prepared according to the method reported previously. ${ }^{4}$

\section{Mono-6-O-[4-(4-phenylazo-phenyl)-poly(ethylene glycol) 600-hydrocinnamoyl]- $\beta$-CD (6-Az-PEG600-HyCiO- $\beta$-CD).}

Mono-6- $O$-[4-poly(ethylene glycol) 600 acid-hydrocinnamoyl]- $\beta$-CD (6-PEG600acidHyCiO- $\beta$-CD, $\left.0.50 \mathrm{~g}, 2.7 \times 10^{-4} \mathrm{~mol}\right)$ and $p$-Aminoazobenzene $\left(0.27 \mathrm{~g}, 1.4 \times 10^{-3} \mathrm{~mol}\right)$ was dissolved in water/DMF $(=20 / 80)$. After the solution was cooled at $5{ }^{\circ} \mathrm{C}$ with stirring, a solution of $\mathrm{EDC} \cdot \mathrm{HCl}\left(0.10 \mathrm{~g}, 5.2 \times 10^{-4} \mathrm{~mol}\right)$ in water/DMF was added. The solution was stirred at $5{ }^{\circ} \mathrm{C}$ for 1 hour, and it was allowed to warm to room temperature and stirred 3 days. Insoluble material was removed by filtration, and the filtrate was concentrated and poured in acetone. After the precipitate was collected and washed with acetone, it was dried under vacuum to give crude product. The crude product was purified by DIAION HP-20 column chromatography. The water/methanol $(=10 / 90)$ eluent was concentrated and dried under vacuum. Yield, $15 \%$. Positive ion MALDI-TOF MS ( $n$; number of ethylene glycol units in PEG): m/z $1903.0[\mathrm{M}(n=7)+\mathrm{Na}]^{+}, 1948.1[\mathrm{M}(n=8)+\mathrm{Na}]^{+}, 1991.4[\mathrm{M}(n=9)+\mathrm{Na}]^{+}$, $2036.0[\mathrm{M}(n=10)+\mathrm{Na}]^{+}, 2080.9[\mathrm{M}(n=11)+\mathrm{Na}]^{+}, 2122.9[\mathrm{M}(n=12)+\mathrm{Na}]^{+}, 2167.6[\mathrm{M}$ $(n=13)+\mathrm{Na}]^{+}, 2210.6[\mathrm{M}(n=14)+\mathrm{Na}]^{+}, 2254.0[\mathrm{M}(n=15)+\mathrm{Na}]^{+}, 2298.6[\mathrm{M}(n=16)+$ $\mathrm{Na}]^{+}, 2345.0[\mathrm{M}(n=16)+\mathrm{Na}]^{+} .{ }^{1} \mathrm{H}$ NMR $\left(\mathrm{DMSO}-d_{6}, 400 \mathrm{MHz}\right): \delta 9.95(\mathrm{~s}, 1 \mathrm{H}$, Az-NHCO-), 9.49 (s, 1H, -CONH-HyCiO-), 7.89 (d, 2H, 2-H, 2'-H of Az), 7.85 (d, 3H, 2-H of Az), 7.58 (t, 2H, 3'-H of Az), 7.55 (t, 1H, 4'-H of Az), 7.52 (t, 2H, 3-H of HyCiO-), $7.16(\mathrm{~d}, 2 \mathrm{H}, 2-\mathrm{H}$ of $\mathrm{Az}), 5.90-5.63(\mathrm{~m}, 14 \mathrm{H}, \mathrm{O}(2) \mathrm{H}$ and $\mathrm{O}(3) \mathrm{H}$ of $\mathrm{CD}), 4.85-4.80(\mathrm{~m}, 7 \mathrm{H}$, $\mathrm{C}(1) \mathrm{H}$ of $\mathrm{CD}), 4.45-4.15\left(\mathrm{~m}, 8 \mathrm{H}, \mathrm{O}(6) \mathrm{H}\right.$ and $\mathrm{C}^{\prime}(6) \mathrm{H}$ of $\left.\mathrm{CD}\right), 4.14\left(\mathrm{~s}, 2 \mathrm{H},-\mathrm{CO}-\mathrm{CH}_{2}-\mathrm{O}-\right)$, $4.05\left(\mathrm{~s}, 2 \mathrm{H},-\mathrm{CO}-\mathrm{CH}_{2}-\mathrm{O}-\right), 3.85-3.17\left(\mathrm{~m}, \mathrm{C}(2) \mathrm{H}-\mathrm{C}(6) \mathrm{H}\right.$ of $\mathrm{CD}$ and $-\mathrm{CH}_{2}-$ of PEG overlaps with $\left.\mathrm{H}_{2} \mathrm{O}\right), 2.80\left(\mathrm{t}, 2 \mathrm{H}\right.$, phenyl- $\left.\mathrm{CH}_{2}-\right), 2.62\left(\mathrm{t}, 2 \mathrm{H},-\mathrm{CO}-\mathrm{CH}_{2}-\right.$ overlaps with DMSO- $\left.d_{6}\right)$. 


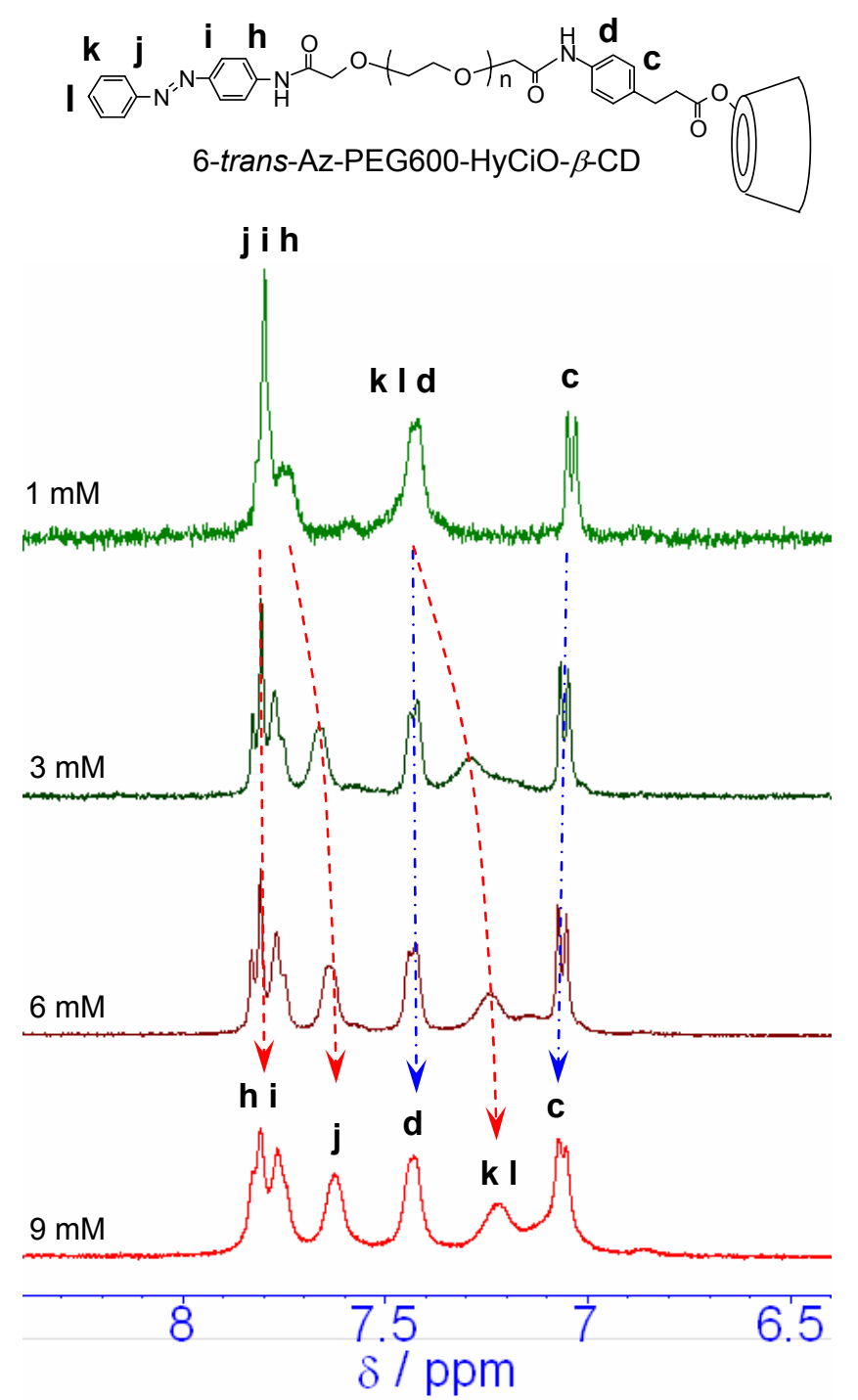

Figure S1. ${ }^{1} \mathrm{H}$ NMR spectra of 6-trans-Az-PEG600-HyCiO- $\beta$-CD in $\mathrm{D}_{2} \mathrm{O}$ at $30{ }^{\circ} \mathrm{C}$ at different concentrations.

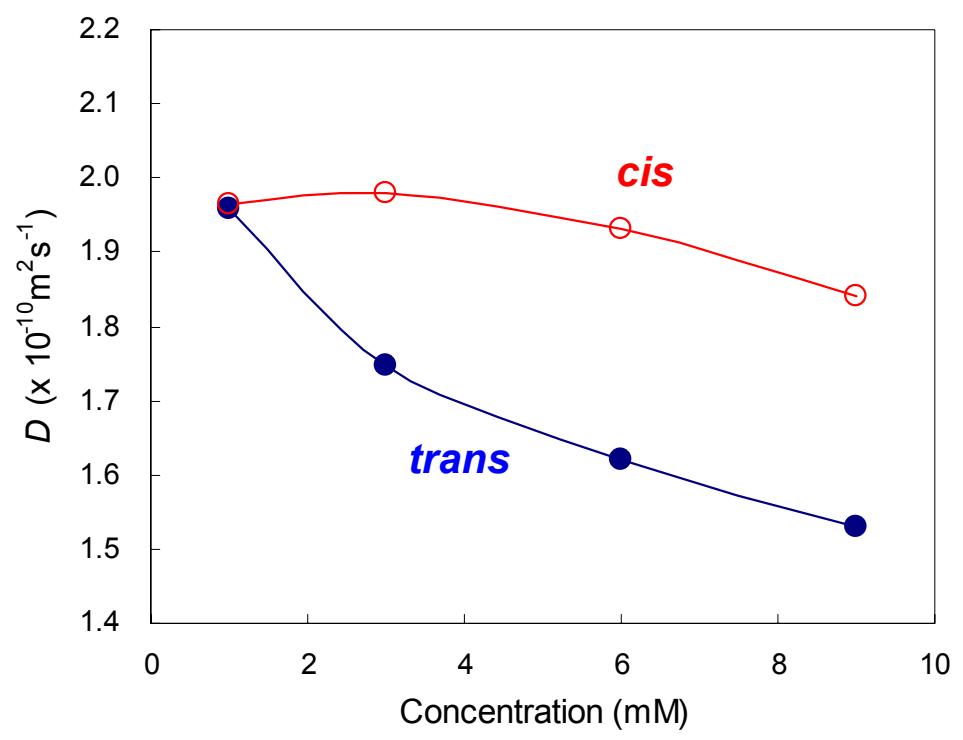

Figure S2. Dependence of the diffusion coefficient of 6-Az-PEG600-HyCiO- $\beta$-CD in $\mathrm{D}_{2} \mathrm{O}$ on the concentration. 


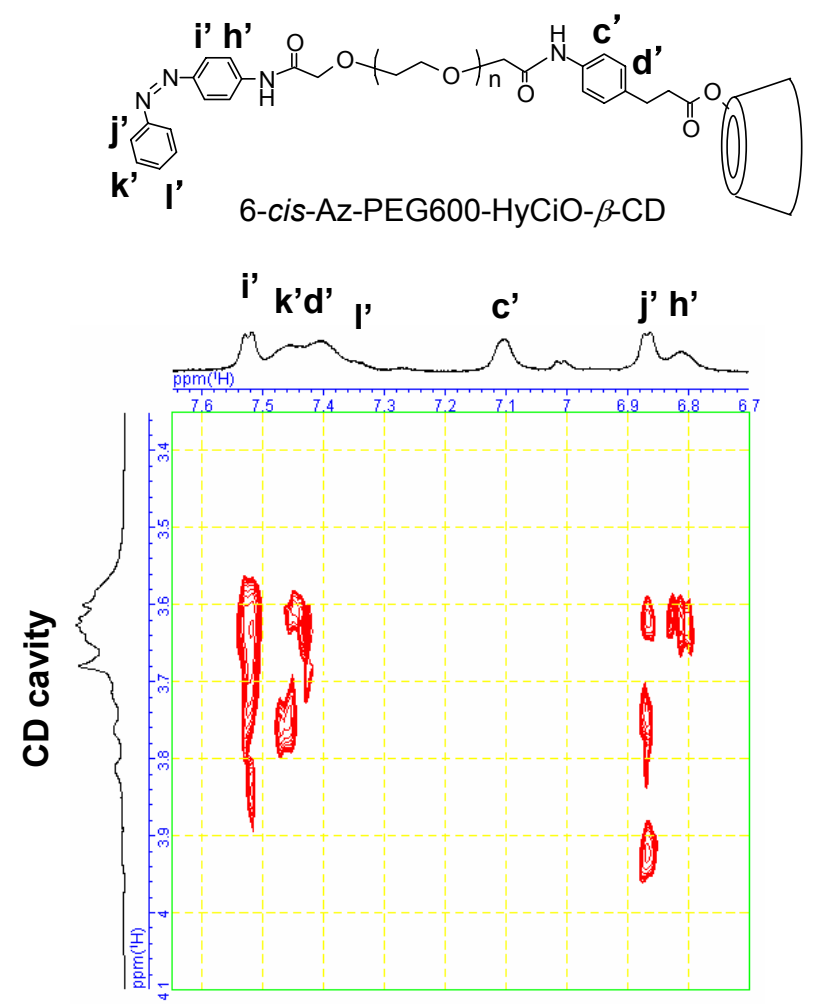

Figure S3. Partial 2D ROESY ${ }^{1} \mathrm{H}$ NMR spectrum of 6-cis-Az-PEG600-HyCiO- $\beta$-CD in $\mathrm{D}_{2} \mathrm{O}$ at $1 \mathrm{mM}$ at $1{ }^{\circ} \mathrm{C}$.

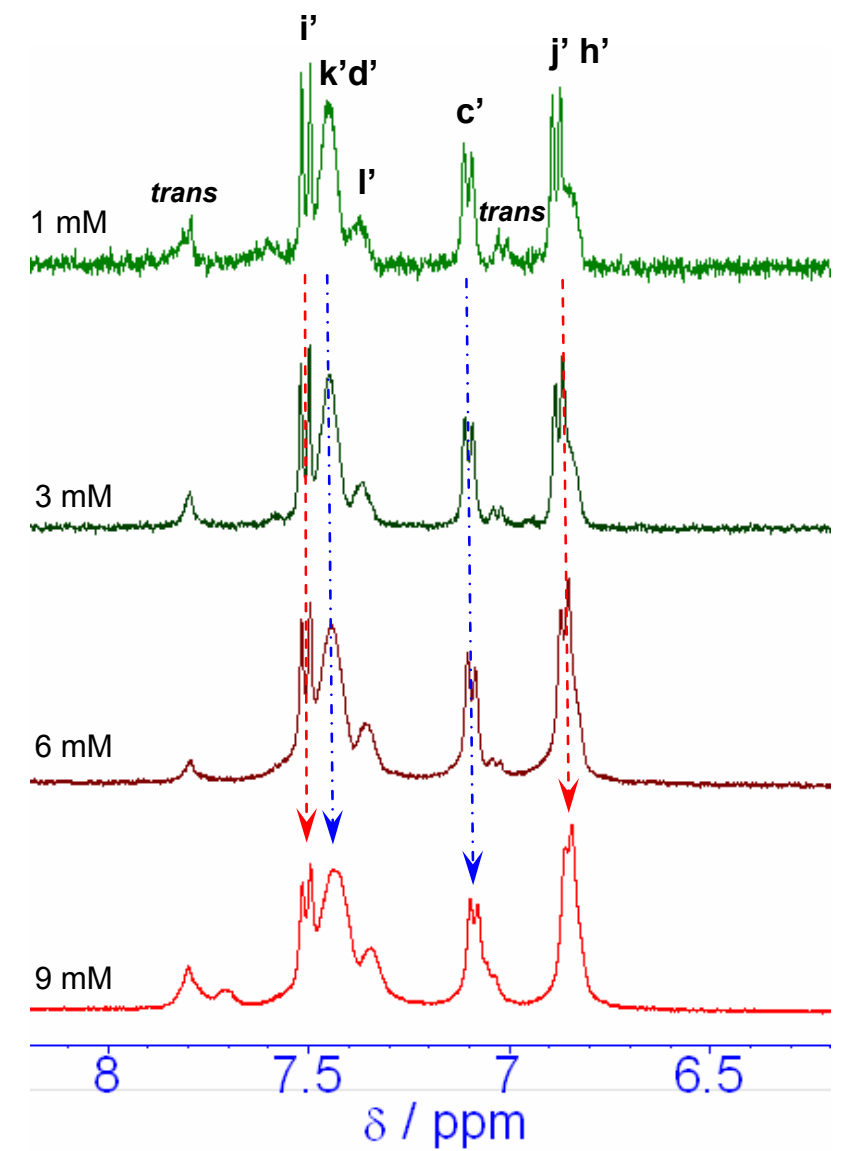

Figure S4. ${ }^{1} \mathrm{H}$ NMR spectra of 6-cis-Az-PEG600-HyCiO- $\beta$-CD in $\mathrm{D}_{2} \mathrm{O}$ at $30^{\circ} \mathrm{C}$ at different concentrations. 

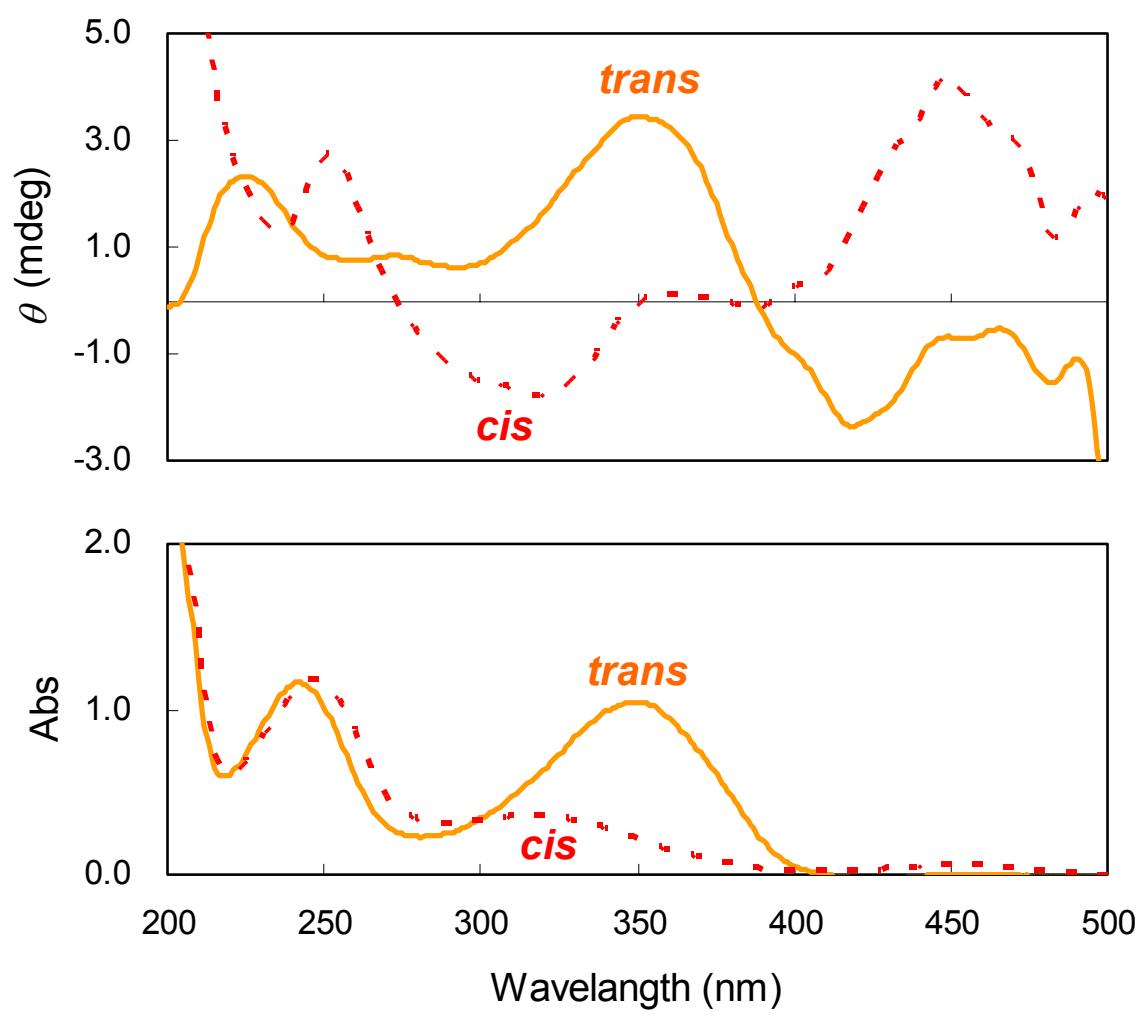

Figure S5. Circular dichroism (upper) and UV-vis (bottom) spectra of 6-trans-Az-PEG600-HyCiO- $\beta$-CD (solid line) and 6-cis-Az-PEG600-HyCiO- $\beta$-CD (dotted line) in aqueous solutions at $0.5 \mathrm{mM}$ at room temperature. 